\title{
Geografiske mønstre for helse, levekår og helsetjenester i Norge: En utvidet anmeldelse og sammenligning av to helseatlas
}

\author{
Stig Jørgensen \\ Helsefag hovedfag, Psykologisk institutt, NTNU 7034 Trondheim \\ Telefon 73597621 Telefax 73591920 E-post stig.h.jorgensen@sv.ntnu.no
}

\begin{abstract}
Nasjonalatlas for Norge: Helse. 1996 (National Atlas of Norway: Health. 1996)
Aase A, Storm-Furru I, forfattere; Nilsen S, hovedred. Statens Kartverk, Hønefoss, 239 sider, tab, ill.

Helse- og levekårsatlas for Hordaland og Noreg. 1996

Hansen FH, Reitan J, Ågotnes J-E, red. Hordaland fylkeskommune og Norges samfunnsvitenskapelige datatjeneste (NSD), Bergen, 191 sider, tab, ill.
\end{abstract}

\begin{abstract}
I 1996 ble det utgitt to omfattende publikasjoner om helse og helsetjeneste i Norge. Begge anvender betegnelsen helseatlas. Først forelå Helse- og levekårsatlas for Hordaland og Noreg fra Hordaland fylkeskommune og NSD. Finn H. Hansen (helse- og sosialdirektør i Hordaland), Jorunn Reitan, og John-Erik Ågotnes står som redaktører og forfattere. Senere samme år utkom Nasjonalatlas for Norge: Helse fra Statens kartverk med Asbjørn Aase (Geografisk institutt, NTNU) og Inger Storm-Furru som hovedforfattere samt Steinar Nilsen som hovedredaktør.
\end{abstract}

Umiddelbart kan det synes påfallende at to svært omfattende kartbøker om helsetilstand og helsetjeneste utgis samtidig $i$ et lite land som Norge. Utgivelsene skyldes nok et stigende behov for å systematisere og sammenstille mengden av informasjon fra ulike kilder om helse, sykdom og levekår på den ene side og helsetjenester og forbruk på den annen. De to publikasjonene betjener seg av økt tilgang til helsedata koblet med en rivende utvikling innen datakartografi. Det kan også nevnes at Sosial- og helsedepartementet (1996) samme år utga Folkehelserapporten om blant annet befolkningens helsetilstand og utviklingstrekk med grafiske presentasjoner og figurer. Det er heller ikke lenge siden to kreftatlas ble publisert, ett om Norge (Glattre et al., 1985) og ett om Norden (Jensen et al., 1988).

Utgangspunktene for atlasene er to uavhengige prosjekt. Statens kartverk startet først, med en oppfølging av en eldre serie om Nasjonalatlas for Norge (om helsetjenesten). Det nye helseatlaset skulle også dekke helse- og sykdomsforhold samtidig som delen om helsetjenesten ble utvidet. Det andre, Helse- og levekårsatlas for Hordaland og Noreg, har sitt utspring i nybrottsarbeid og særlig interesse i én fylkeskommune for å framskaffe datagrunnlag i forbindelse med ny helse- og sosialplan. En hovedhensikt har vært å sammenligne interne geografiske forhold i fylket. Etter hvert framsto også et tydeligere ønske om eksterne sammenligninger, mot helse og helsetjeneste $i$ andre fylker (helseregioner).

Siktemålet i denne anmeldelsen er ikke bare å gi en oversikt over innhold og framstillingsmåter for helseaspekter i hvert atlas. Det er også interessant å sammenstille opplegg og utforming av de to atlasene. Hvilke temaområder vektlegges? Hvordan presenteres stoffet? Hva er grunnlaget for ulikheter i profilering, og hvilke sammenhenger (samvariasjoner) søker publikasjonene å belyse? I det følgende benevnes atlasene henholdsvis Nasjonalatlaset og Hordalandsatlaset.

\section{FORMÅL MED ATLASENE}

Begge atlasene har som formål å presentere helse og helsetjeneste samt andre relaterte forhold. En mest mulig allsidig informasjon er søkt bearbeidet. Søkelyset rettes mot geografiske forskjeller og utvikling over tid. Atlasene henter store deler av sitt datatilfang fra de samme kilder og dekker omlag samme tidsperiode, dvs. fra 1970-tallet fram til de tidligste 1990-årene for de mest utbredte tema.

Kartlegging av mønstre og beskrivelser av tilstander har forrang framfor mer penetrerende analyser av (mulige) årsaksforhold bak påviste variasjoner. Selv om atlasene inneholder tabeller og figurer, benyttes kartografi som det bærende prinsipp for presentasjon av data og visualisering. Begge atlasene benytter koroplettkart, som er kartbilder basert på områdenes faktiske areal som så gies en fargetone bestemt av den verdiklasse det enkelte området er tilordnet. 
Både Nasjonalatlaset og Hordalandsatlaset framhever å ha nytteverdi og relevans for plan- og strategiarbeid knyttet til utbygging og fordeling av såvel helsetjenestetilbud som helsefremmende og forebyggende arbeid.

Hordalandsatlaset har ett fylke og dets interne variasjoner som hovedfokus, men med sideblikk på de andre fylkene i landet. Størstedelen av Nasjonalatlaset har en "balansert" tilnærming uten søkelys på spesielle regioner. Etter en slik systematisk tilnærming portretterer atlaset noen særskilte områder i landet i et regionalgeografisk perspektiv. Vestlandet stilles opp mot Finnmark og Oslo som ytterpunkter langs en nasjonal akse. Helseprofilene til de to sistnevnte områder skarpstilles.

Som vi kommer tilbake til, er de tematiske profilene også noe ulike. Hordalandsatlaset vil framlegge et bredest mulig datagrunnlag. Nasjonalatlaset avgrenser temaområdene i større grad og velger å gå dypere inn i omtalen av disse.

\section{ET GEOGRAFISK UTGANGSPUNKT}

Naturligvis vil den geografiske dimensjon stå sentralt i atlasene. Helsedata med geografiske kjennemerker gir grunnlag for å pensle ut by-landforskjeller såvel som framstillinger på ulike geografiske nivå. Disse nivåene er, med få unntak, ordnet $\mathrm{i}$ et hierarki fra helseregioner, til fylker, sykehusområder (opptaksområder for sykehus), handelsdistrikt, kommuner og ned til bydeler i storbykommuner. De fleste datasett relatert til helse har kommune som minste databærende enhet. Begge atlasene presenterer data på dette nivå, blant annet knyttet til primærhelsetjenesten. Ellers utnyttes kommune som "byggesten" til ulike regioninndelinger $i$ atlasene. Ved presentasjon av helseforhold i Nasjonalatlaset velges gjennomgående fylker med en systematisk inndeling $\mathrm{i}$ by og land. Bymessige områder skilles ut på grunnlag av tettsteder som inngår i kommuner med mer enn 10000 innbyggere. En slik byland dimensjon anvendes imidlertid ikke ved presentasjon av helsetjenester.

Hordalandsatlaset vier interne variasjoner i fylket stor plass. Her får sykehusområder en sentral posisjon, og seks områder avtegnes: Stord, Odda, Voss, EtneØlen-Sveio (tre kommuner som egentlig tilhører sykehusområdet Haugesund i nabofylket) og to områder for Bergen. Forfatterne velger her å ta ut Bergen kommune som et eget område. Også på fylkesnivå er Bergen skilt ut. Derved oppnår en å få fram en by-land effekt eller snarere å trekke ut en storbydimensjon fra Vestlandsfylket. Når data tillater det, presenteres også bydeler i Bergen. For nasjonale sammenligninger benyttes hovedsakelig fylkeskart, ledsaget av diagrammer for helseregioner.

Begge atlasene tar oss gjennom forsøk på geografiske synteser der mange helseaspekter trekkes sammen til helhetlige helsebilder av områdene. I
Hordalandsatlaset vektlegger en ikke på samme måte en verbal sammmenbinding, men utvikler regionbeskrivelser videre $\mathrm{i}$ form av sammenstillinger av indikatorer som komprimeres $\mathrm{i}$ indekser og oppsummeringsmål for helse og tjenestetilbud.

\section{INNHOLD OG VALG AV TEMA}

Atlasene har valgt en nokså parallell tematisk ordning for å belyse de enkelte helseytringer og tjenester.

Hordalandsatlaset tilrettelegger et vidt felt for kartpresentasjoner og grafiske framstillinger. Innledningsvis gies en orientering om hvorfor et slikt atlas publiseres etterfulgt av en noe kortfattet gjennomgang av valgte presentasjonsmåter og metoder. Videre er kartboken tredelt.

Del I omfatter helse- og levekår, som åpnes med to kapitler om de hyppigste dødsårsaker fulgt av kreftformer basert på insidensdata. Deretter følger omtale av andre helseforhold med egenrapportert helse, ulykker, tannhelse, medisinbruk og AIDS/HIV og gonoré. Et eget kapittel belyser risikofaktorer for infarkt, som kokekaffe, fysisk aktivitet, røykevaner og alkoholforbruk. Levekår omtales deretter i en egen del med indikatorer som boligforhold, utdanning, inntekt, enslige forsørgere og forurensning mv., samt forsøk på å konstruere samlede levekårsindekser. Sist i Del I blir befolkningens alders- og kjønnssammensetning kort presentert.

Del II omhandler tjenestetilbud og bruk av helsetjenester med i alt syv kapitler. Først kommunehelsetjenesten (sykehjem, hjemmesykepleie mv.) med kontaktmønster, dernest helse- og sosialsektoren (utgifter, forbruk og personell), og så somatiske sykehus (ressurser, forbruk og noen operative inngrep). Deretter følger et kort kapittel om fødselsdata. De tre temaene psykisk helsevern (sykehjem og sykehus), barnevern og sosial- og trygdeytelser er videre tildelt hvert sitt kapittel.

Del III gir en oppsummering og presentasjon av profiler der helse, levekår og forbruk/kapasitet for tjenester er sammenfattet. Her dyrkes forskjeller internt i Hordaland, men også fylkets posisjon vis-á-vis andre fylker. Avslutningsvis sammenstilles utvalgte helseindikatorer til riss av fylkesprofiler, og med en invitt til mer gjennomgripende analyser.

Nasjonalatlaset består av to deler. Del I omfatter helsetilstanden med syv kapitler: Først gies en fyldig innledning, dog med en noe misvisende tittel om god og dårlig helse, som også omfatter en geografisk innfallsvinkel, regionaliseringsproblemer, temavalg, måling av helse og endringer over tid. Levealder og dødelighet er tatt opp i et kort kapittel. De neste kapitler omtaler de viktigste dødsårsaker og kreftsykdommer basert på insidenstall. Hyppighet av andre sykdommer og lidelser vies et kapittel der forskjellige datakilder presenteres dels ved at vi får innsyn gjennom såkalte "sykdomsvinduer". Data om uførhet 
framstilles og suppleres med opplysninger om infeksjonssykdommer, de hyppigste kjønnssykdommer og HIV/AIDS. En del omhandler risikofaktorer og eksposisjoner. Metodeproblemer drøftes og UV-stråling, røyking og alkoholvaner blir belyst. Del I avrundes med et regionalgeografisk perspektiv der underliggende faktorer som bidrar til regionale helseprofiler trekkes fram. By-land dimensjonen fokuseres, og kjennetegn ved Vestlandet og dets "motstykke" Finnmark betraktes i et tidsperspektiv. En nærmere presentasjon av Oslo gir innblikk i geografiske helseulikheter i en storby.

Del II beskriver helsetjenester. Det første av fem kapitler gir bl.a. et overblikk over helsetjenestens geografi, og videre tjenestetilbud. Grunnlaget for atlas og kartografi samt datakilder omtales, noe som også ble gjort i helsedelen og gir inntrykk av at atlaset består av to atskilte deler. Neste kapittel gir hovedtrekk ved helsevesenets utvikling. Kommunehelsetjenesten er tildelt et eget fyldig kapittel med helsepersonell, helsestasjonstjenesten, allmenlege- og fysioterapitjenesten samt pleie- og omsorgstjenester. Fylkeskommunale og statlige helsetjenester omhandler regionalisering og nivådifferensiering og presenterer somatiske sykehus med virksomhetstall og tilsvarende psykiatriske institusjoner innenfor rammen av et kapittel. Sluttkapitlet gir nærmere oppslag om helsetjenestens geografi blant annet ut fra likhetsbetraktninger. Et forsøk på å sammenstille opplysninger om helse (dødelighet) og helsetjeneste (legedekning) blir gjennomført med fylker som utgangspunkt. Så følger kartografiske presentasjoner av alderssammensetningen samt andre geografiske forhold (periferi-utkant, avstander og reisetider). Sluttord handler om Norge i verden.

Begge atlasene kunne tjent på å ta inn en oversikt over befolkning med sammensetning og endring i en innledende del. Områdenes kjønns- og aldersstruktur inngår som et viktige referansegrunnlag for å få grep om forskjeller i sykdomsmønster og tjenestetilbud. Et slikt avsnitt kunne vært naturlig integrert $i$ en gjennomgang av valgte geografiske enheter og regioninndelinger. Leseren ville da hatt demografiske forhold i mente ved nærmere tolkninger av helsesituasjoner og deres utvikling.

Hordalandsatlaset går vesentlig lengre i å trekke inn levekårsdata og sosialtjenester, bl. a. vies enkelte trygdeytelser ved sykdom og arbeidsledighet nærmere oppmerksomhet. Men også på helsesiden vides spekteret av risikofaktorer ut ved å benytte hjerte-karundersøkelsene (40-42 åringer) fra Statens helseundersøkelser. I delen om helsetjenester er det spesielt sykehustjenesten som brettes ut med forbruksmønstre for utvalgte pasientgrupper og operative inngrep. Også fødselsdata med komplikasjoner og keisersnitt inngår. Derimot er kapitlet om helsetjenesten i kommunene mindre omfangsrikt enn i Nasjonalatlaset.

Gjennomgående presenterer Hordalandsatlaset et materiale med mer oppdaterte tidsperioder. Det er ett til to år forskjell for de fleste datasett om helse og helsetjeneste, noe som kan tilskrives ulik tidsbruk knyttet til redaksjonsarbeid og endelig ferdigstilling. Det skyldes også ulik tilgang og bruk av databaser, f.eks. når Nasjonalatlaset bare opererer med dødelighetsdata fram til 1989, mot 1993 i Hordalandsatlaset.

Bare Hordalandsatlaset gir tidsserier for kreftinsidens (1973-82, 1983-92). For øvrig velges ulike tidsperioder og dels forskjellige standarder for sammenligning i de to atlasene. Det gjelder ikke minst presentasjon av ressursfordeling som helsepersonell der det foreligger flere grunnlag for sammenligninger.

Nasjonalatlaset sin helsedel har et meget instruktivt innledende oppslag av mer generell karakter med tilnærmingsmåter og modeller som setter metodespørsmål inn $\mathrm{i}$ en videre ramme. Her trekkes f.eks. den økologiske sykdomsmodell, med biologi/arv, atferd og miljø som grunnelementer, inn for å belyse samspill mellom påvirkningsfaktorer for sykdom. Teksten poengterer og binder sammen kartpresentasjonene på en stimulerende måte. Også i delen om helsetjenester ledsages kartframstillingen av en omfattende tekstdel. Forfatteren gjengir hovedtrekk i helsetjenestens utvikling, organisering og finansiering samt helsepolitiske aspekter knyttet til likhet og fordeling. Til sammen forsterker dette inntrykket av at Nasjonalatlaset er mye mer enn en kartbok.

Hordalandsatlaset har ikke på samme måte lagt opp til en vid beskrivelse omkring de valgte tema. Forfatterne velger i større grad å behandle enkelte metodespørsmål i direkte sammenheng med presentasjon av de ulike datasett. Også de andre kommentarene er mer eksplisitt knyttet til respektive kartbilder. Naturlig nok tildeles Hordaland spesiell oppmerksomhet, men uten at dette tar overhånd slik at framstillingen får en "provinsiell" karakter.

\section{STATISTISK SIKKERHET OG EGNETE GEOGRAFISKE ENHETER}

I datakartografi står en overfor en rekke valg og metodeproblemer ved framstilling av epidemiologiske data (Cliff \& Haggett, 1988; McGlashan, 1990). Noen omtales her. Kartpresentasjoner for små geografiske enheter reiser uvilkårlig metodespørsmål knyttet til krav om statistisk utsagnskraft og hvorvidt de mønstre som utfelles kan skyldes tilfeldigheter. Desto lavere folketall i de geografiske områdene, sjeldnere fenomener (lavere rater) og kortere observasjonsperioder, desto større varsomhet må utvises overfor signifikansproblemer. Den generelle løsningen når små og usikre tall opptrer er å aggregere data til et høyere geografisk nivå eller å utvide observasjonsperioden.

Hordalandsatlaset håndterer ikke problemet med usikre rater og statistisk signifikans på en fullgod måte. I atlasets innledning, under avsnittet om grafisk presentasjon, omtales forsøk på å benytte standardavvik og relatere dette spredningsmålet til områder 
som "er signifikant forskjellig". Poenget forblir uklart og denne framgangsmåten faller ikke helt heldig ut. For noen kart har en valgt å utelate områder med lave og usikre rater bare ut fra et kriterium basert på små absolutte tall. Det gjelder f.eks. fylker med få alkoholrelaterte dødsfall for kvinner når antall døde er under 21. (Det blir imidlertid misvisende når disse områdene markeres med 'data mangler'.) En svakhet er at det ikke beregnes grenseverdier for når områderater avviker fra nasjonale rater med et eksakt signifikansnivå. I stedet beregnes et minste antall døde i områdene. Men siden dette tallet jo avhenger av folketall og forholdet til nasjonal rate, blir usikre rater presentert for enkelte geografiske områder. Kriterier for områder som skal utelates og områder som presenteres med usikre rater forblir diffuse.

Problemet dukker opp gjentagne ganger og blir påtrengende når alle Hordalandskommunene presenteres. Her inngår noen av landets minste kommuner som Modalen og Fedje med langt under 1000 innbyggere. I noen av de påfølgende kart presenteres antagelig en del ikke-signifikante rater og det foretas en stjernemerking av kommuner med små tall, men her med færre enn 10 tilfeller. Markeringene gjennomføres ikke konsekvent (f.eks. ikke for trafikkskadde og enkelte operative inngrep). En oppnår på denne måten å signalisere oppmerksomhet omkring få observasjoner og usikre tall uten å ta skrittet fullt ut med en tilstrekkelig avgrensning av problemet med usikre rater.

På fylkesnivå trekkes av og til for sterke slutninger om utvikling i mønstre og derved også Hordaland sin situasjon på grunnlag av spinkle tallgrunnlag. Det berører bl.a. enkelte aldersgrupper for dødelighet av hjerneslag (1974-83 og 1984-93) og trolig også alkoholrelaterte dødsfall for disse periodene.

På kommunenivå må en som regel være enda mer vaktsom med små tallmaterialer som for hjerte-karundersøkelsene (40-42-åringer). Forfatterne viser her nødvendig tilbakeholdenhet.

Flere interne variasjoner i Hordaland kan likevel belyses relativt inngående med tilstrekkelig statistisk sikkerhet. Ofte unngås omfattende problemer med usikre tall ved presentasjoner av rater på sykehusområder som naturligvis er mer robuste statistiske enheter. Denne område-enheten er også interessant fordi den gjerne faller sammen med såkalte funksjonelle regioner dvs. et naturlig omland til et stort tettsted (sykehuskommunen). Slike sykehusområder framstår som mer homogene enheter enn fylker. Den første områdeenheten gir dessuten utvidete muligheter for å knytte sammen epidemiologiske data og helsetjenestedata. Sykehusområder representerer imidlertid ikke et forvaltningsnivå. Således mangler grunnlaget for tydelige helsepolitiske beslutninger på dette nivået dersom en ønsket å påvirke sykdomsmønstre og tjenestetilbud.

Problemet med å avklare signifikante geografiske forskjeller er viet langt større oppmerksomhet i Nasjonalatlaset sine helsekart. Forfatteren har et sikrere grep om problematikken med eksakt angivelse av signifikansnivå og bruk av symboler når fylker viser negative eller positive avvik fra nasjonale rater for de fleste datagrunnlag. Derimot blir denne problematikken oversett i noen aktuelle kapitler i delen om helsetjenester. Oppgaven er dertil mer presserende her med presentasjoner på kommunenivå for kortere tidsperioder. Mange kommunekart har et tallmateriale basert på enkeltår. I flere av disse kartene er det grunn til å betvile i hvor stor grad mønstrene som avspeiles er signifikante. Notoriske innslag av usikre høye og lave verdier for kommuner vil forekomme. F.eks. gjelder dette kartet som skal illustrere veksten i legedekning i kommunene, uttrykt ved legeårsverk pr. innbygger 1993 som andel av årsverk pr innbygger i 1989. Det er her statistisk usikkerhet knyttet til både teller og nevner for mange kommuner. I sin tur begrenser det mulighetene for å trekke konklusjoner om endringer i slike mønstre.

$\AA$ ta fullt ut hensyn til problemer med statistisk usikkerhet for geografiske områder er ofte arbeidskrevende, men viktig. Slike beregningsmetoder er som regel heller ikke tilstrekkelig integrert eller tilrettelagt ved datauttak og oppbygning av databaser.

\section{KARTPRESENTASJONER OG GRAFISKE FRAMSTILLINGER}

Nasjonalatlaset har en ryddig presentasjon av kartbilder. Ofte avbildes kart parvis der to tidsperioder vises fordelt på menn og kvinner, eller ett kart for kvinner og ett for menn for samme tidsperiode. Prinsippet med sammenstilling av kart for to tidsperioder beholdes også for helsetjenester og bidrar til et enhetlig preg.

Hordalandsatlaset presenterer derimot svært komprimerte kartsider. I et typisk bilde inngår parvise kart, oppdelt etter tidsperioder, som viser fylkets sykehusområder. Av og til innlemmes også kommunene. I det samme bildet inngår korresponderende kart som viser alle fylker. Dertil vises grafikk med kurver og stolpediagram over utvikling i helseregioner, sykehusområder eventuelt kommuner eller bydeler i Bergen. Overraskende nok blir disse kartsidene bare sporadisk overlesset med informasjon. På den annen side krever den fortettede temapresentasjonen tid til å sortere ut essensen $i$ et materiale som avbildes med opptil fem geografiske nivå på samme kartside.

I kartografifaget er det kjent at fortolkninger av den kartografiske presentasjonen kan påvirkes av de valgte klasseinndelinger (antallet klasser og klassebredde) samt prinsipper for fargevalg knyttet til disse. Alle lesere er nok ikke klar over betydningen av karttegningsteknikk samt fargeskala og fargetoner som knyttes til de enkelte verdiklasser. I alt åpner disse valgene for langt videre manipuleringsmuligheter enn tilfellet er for tabellframstillinger fordi det visuelle inntrykk spiller en så avgjørende rolle ved studier av geografiske mønstre. Koroplettkart kan gi slående eksempler, med arealmessig store kommuner med små befolknin- 
ger som ofte oppviser ikke-signifikante høye eller lave verdier. Når områdene samtidig tildeles skarpe fargetoner, som rødt og blått, tiltrekker de seg uforholdsmessig stor oppmerksomhet og kan fordreie fortolkning av mønstre. Noen slike presentasjoner finnes $i$ delen om kommunehelsetjenesten i Nasjonalatlaset. Eksempelvis illustrerer et kart endringer i personellinnsats i eldreinstitusjoner 1989 sammenlignet med 1993, med fargevalg som bidrar til et overdrevent inntrykk av markante prosentvise endringer for en del kommuner. I Finnmark framstår tilsynelatende sterke kontraster som knyttes til arealstore kommuner som Lebesby og Kvalsund (sterk rød farge) og Kautokeino og Karasjok (blå farge). Tilsvarende kontraster er også iøynefallende i landkommuner i Nordland, NordTrøndelag og Hedmark. Totalt sett kan dette påvirke det geografiske bildet for hele landet. Et øvet blikk er ofte nødvendig for å fange opp et mer komplisert mosaikk-bilde for endringer i folkerike, men arealmessige små kommuner - som egentlig kan oppvise de største utslag (jf. kommuner rundt Oslofjorden).

Paralleller til dette forekommer i Hordalandsatlaset. Usikre kommunerater for grisgrendte kommuner som Modalen og Eidfjord står fram med røde verdier for utvalgte risikofaktorer, f.eks. for kvinner $i$ 40-42-årsalderen med høyt blodtrykk og høy kroppsmasseindeks.

Kartografer argumenterer for å velge en bestemt fargeskala og med regelmessig fargetone for høye og lave verdier for alle variable som blir avbildet på kart. En slik standardisering vil gi et grunnmønster og framstå som et gjenkjennelsesprinsipp for leseren. Hordalandsatlaset velger et slik ledetråd ved å benytte fem faste verdiklasser (kvintilinndeling). Samme farge og fargetoner er tilordnet disse klassene gjennom hele atlaset. Men i andre grafiske presentasjoner (for helseregioner, sykehusområder) bryter en med et slikt standardisert opplegg.

Nasjonalatlaset faller for tillokkelsen til å endre fargetoner og skalaer fra kartbilde til kartbilde. Fargekombinasjoner endres i unødig stor grad. Sammen med at antallet verdiklasser og fargetoner skifter mellom temaområder i atlaset, gir dette en viss kaleidoskopisk og forstyrrende effekt. I den grafiske delen endres derimot ikke farger på kurver for aldersgrupper fra emne til emne.

\section{NOEN HOVEDFUNN OG GEOGRAFISKE MØNSTRE}

Noen få bruddstykker fra atlasene som presenteres her kan ikke yte rettferdighet til atlasenes vell av interessante mønstre og utviklingstrekk.

Nasjonalatlaset har lyktes i å få fram en by-land dimensjon på fylkesnivå som har vært mindre påaktet $\mathrm{i}$ tidligere deskriptiv epidemiologi. Basert på en slik todeling avdekkes dødelighetsmønstre for hjertekarsykdom som er markert forskjellige fra de en finner for samlete kreftsykdommer. Kreftdødelighet er høyere i byene. Dødeligheten økte fra 1970-tallet til 90-tallet, men by-landmønsteret er omtrent uendret over tid. For koronar hjertesykdom har utviklingen vært mer sammensatt ved at byområder har beveget seg fra en høyere dødelighet enn landsbygda på 70tallet til en lavere etter midten av 80-tallet. Dødeligheten gikk ned i byene i hele perioden, mens på landsbygda begynte ratene først å synke rundt 1980 og reduksjonen har vært svakere enn i urbane områder. Det er små kjønnsforskjeller i disse forløpene. Utviklingstrekkene for hjertesykdom fortolkes som en geografisk diffusjonsprosess med vekt på hvordan endringer i helseatferd spres ut fra de største byområdene. Instruktive grafer over utviklingsforløpet for menn og kvinner gir god støtte for resonnementene.

I et meget velskrevet kapittel utdyper Asbjørn Aase et regionalgeografisk perspektiv og særskilte områder sine helseprofiler. Ulike ledetråder fra kart i den systematiske delen føres sammen på en overbevisende og pregnant måte. Her karakteriseres hovedtrekk ved by-landmønstre. Vestlandet, inklusive Bergen, sin gunstige situasjon kontrasteres mot Finnmark som det andre ytterpunkt. Det antydes for øvrig at nyere tall for helserisiko, forbundet med røyking og alkohol, gir indikasjoner på at Vestlandets tradisjonelt fordelaktige posisjon kan være i ferd med å undermineres fordi yngre aldersgrupper tar opp helsevaner som ikke lenger avviker vesentlig fra landsgjennomsnittet. Gjennom to case-studier, Finnmark og Oslo, får leseren også godt innsyn i de indre variasjoner i disse så forskjellige regionene. Det tegnes et utfyllende bilde av påfallende interne helseulikheter: I nord med dårlig stilte fiskerikommuner ytterst langs kysten i forhold til mindre ugunstige fjord- og innlandsområder i fylket. I storbyen er det store kontraster i helse mellom bydeler der østkant-vestkant representerer et markert skillelinje. Særegne, underliggende forhold ved levekår og sykdomsmønstre veves sammen til nyanserte forklaringer på framvekst og utvikling av slike regionale helsesituasjoner.

Også helsetjenestedelen i Nasjonalatlaset belyser trender og tendenser. Ofte er det korte tidsperioder (enkeltår) som sammenlignes langs en kortere tidsakse. Leseren får likevel innblikk i helsetjenestens variasjoner knyttet til behov, kostnadsstruktur og forbruk på kommune- og fylkesnivå. En sentrum/periferidimensjon felles ut for fylker, likeledes avdekkes strukturelle trekk knyttet til store og små kommuner for enkelte typer tjenester slik som eldreomsorg. Like fullt har noen tema som nevnt et tallmateriale som kan bære preg av usikkerhet enkelte steder og langsiktige utviklingstrekk kommer ikke alltid klart til syne.

Bare i beskjeden grad forsøker Nasjonalatlaset å trekke tråder mellom helsetilstand og helsetjenester. I et avsnitt belyses forholdet mellom legeårsverk i primærhelsetjenesten og samlet dødelighet på fylkesnivå, med en by-land-oppdeling. Legedekningen er lavere $\mathrm{i}$ 
byene enn på landsbygda. Det konstateres kortfattet at dette tjenestetilbudet varierer omvendt med dødelighetsmønsteret.

Hordalandsatlaset viser også nasjonale variasjoner og trender for fylker og helseregioner og interne variasjoner i Hordaland. Der datagrunnlaget ligger til rette presenteres også forskjeller på bydelsnivå i Bergen, som gjerne avslører markerte kontraster slik som for innbyggernes bruk av sykehustjenester. Gjennom å operere med så mange geografiske inndelinger på en gang raffineres presentasjonene samtidig som de tilføres økt kompleksitet.

I Hordalandsatlaset forsøker forfatterne å oppsummere helse- og levekårsforhold basert på fylkesvise rangeringer for enkeltindikatorer. Den valgte metodikken har sine påpekte svakheter, men får også tak $\mathrm{i}$ noen essensielle strukturer. For helse kommer "Vestlandseffekten" til syne ved at Sogn og Fjordane ofte kommer best ut fulgt av Hordaland uten Bergen. Men også hele Hordaland inntar en gunstig posisjon. Disse trekkene ser i særlig grad ut til å være gyldig for kvinner. For fylkets sykehusområder inntar Sunnhordland og Bergen by ytterposisjoner. Tilsvarende levekårsoppsummering bekrefter i store trekk dette bildet. Det foreligger en sterk samvariasjon på fylkesnivå mellom samlete helse- og levekårsmål $(\mathrm{r}=0,84)$, men dette gjenfinnes ikke på sykehusområdenivå i Hordaland.

Det er ikke overraskende når en finner at helsetilstand i fylkene ikke samvarierer på noen enkel måte med befolkningens bruk av somatiske sykehus. Men for sykehusområdene i Hordaland foreligger en positiv sammenheng, det vil si desto dårligere helserangering desto høyere sykehusforbruk. Antagelig vil mange paradokser og anomalier komme til syne ved nærmere studier av slike mønstre. Sammenstillinger av helseforhold og helsetjeneste underbygger tidligere inntrykk av at disse hovedemnene i større grad er fors $ø \mathrm{kt}$ integrert i Hordalandsatlaset. Forfatterne vil ikke gjennomanalysere slike forhold og vokter seg for å trekke konklusjoner. De har likevel oppnådd hensikten: å vekke nærmere faglig interesse og pirre den metodiske nysgjerrighet.

Hordalandsatlaset etterlyser i flere sammenhenger større vekt på en etterspørselsorientert planlegging av helsetjenester som tar hensyn til forskjeller i behov og sykdomsmønster. En kan spørre seg hvorfor det er så komplisert å trekke nivåsammenligninger mellom helsetilstand og tilbud i helsetjenesten. Muligheter og begrensinger ved å stille helse og helsetjeneste opp mot hverandre kan drøftes nærmere - noe uavhengig av atlasenes presentasjoner.

\section{SAMMENSTILLINGER AV DATA OM HELSE OG HELSETJENESTE}

Et nærliggende spørsmål når sykdomsmønstre presenteres sammen med tilbud og bruk av helsetjenester er dette: Er bruk av helsetjenester rimelig (rettferdig) fordelt i forhold til forskjeller i sykelighet og helsetilstand? Det har vært vanskelig å få et godt grep om samsvar mellom geografiske fordelinger av behov (etterspørsel) og tilbud. Innen f.eks. medisinsk geografi har en tradisjonelt dekket dette feltet gjennom de to retningene 'geografisk epidemiologi' og 'helsetjenestens geografi', men det har vært et klart skisma mellom disse (Mayer, 1982). Få forsøk på bygge broer mellom feltene er gjennomført.

Utvilsomt kan noen vanskeligheter med å sammenligne data om helse og helsetjeneste tilskrives ulike registreringsmåter og målemetoder. Det oppstår problemer dersom en anvender ulike telleenheter: personer i epidemiologi versus pasienter med ett eller flere opphold (konsultasjoner) i helsetjenesten. Ofte anvendes forskjellige rater i sammenstillinger - standardiserte mot ikke-standardiserte - og ulike tidsperioder. Slike problemene er til stede i Nasjonalatlaset sitt eksempel der dødelighet sammenholdes med legedekning på kommunenivå. En må også kunne ta hensyn til tidsforskyvninger mellom helsetilstand og bruk av helsetjenester. Dødelighet som helseindikator, bør helst kunne sees i sammenheng med tjenestetilbud $i$ en viss periode før død.

Mål på forekomst av sykdom, som insidens og prevalens, kan selvsagt ikke gi uttrykk for absolutte behov for helsetjenester. Sykdom og behov må betraktes i relasjon til behovsintensitet (sykdommers alvorlighetsgrad) og behovsdekning (nytteverdi av behandling). Akutt versus kronisk lidelse har betydning her. Mål på helse tar heller sjelden hensyn til hvorvidt den syke oppsøker og bruker forskjellige tilgjengelige helsetjenester. Tilgang og bruk av tjenester påvirkes av samspill mellom behandler og pasient og ofte komplekse sosiokulturelle atferdstrekk ved disse aktørene. Pasienter øver ulikt påtrykk for behandling. Leger kan utøve forskjellig skjønn og klinisk praksis bl.a. knyttet til liberale eller strenge indikasjoner for behandling eller henvisning. Hertil kommer effekter av tilbudsstruktur og kapasitet slik som tilbudsgenerert etterspørsel. Helsetjenestetilbud er mangeartet og for en rekke sykdommer vil det videre foreligge substitusjonseffekter og alternative valg (primær- og spesialisthelsetjeneste, ambulant tjeneste og institusjonstjeneste).

Når alle sykdommer betraktes samlet, vil en således kunne få samlede effekter som summerer seg opp på uoversiktlige måter og gjør direkte sammenligninger med tjenesteforbruk besværlig. Med dødelighet og typiske risikofaktorer (f.eks. røyking) som helseindikatorer, fanger en ikke opp sykehusforbruk for ortopediske lidelser, ØNH- og øyesykdommer o.a. med lav dødelighet og svakere assosiasjoner med en del vanlige risikofaktorer. Høy dødelighet for enkelte sykdommer som infarkt og kreft kan i vekslende grad innebære både et høyt og lavt sykehusforbruk (innleggelser).

Alt dette bidrar til at det blir komplisert å bedømme om det er et godt samsvar mellom helsetilstand og 
helsetjenesteforbruk i et geografisk område. De nevnte forhold har relevans for Hordalandsatlasets sammenstilling av "summert helsetilstand" sammenlignet med sykehusbruk. Det er ikke dermed sagt at en ikke skal våge slike sammenstillinger og analyser. En vurdering av samsvar mellom behov og tjenestetilbud på grunnlag av denne type grove resultatstørrelser må utøves med kritisk sans. Etter som ulike indikatorer trekkes inn er det grunn til å gjennomføre følsomhetsanalyser og kontroll av robusthet. Særlig gjelder det hvis de skal være bærende premisser i utforming av helseplaner og fordeling av helsetiltak.

En annen tilnærming er å studere profiler og mønstre for enkelte sykdommer i stedet for samlemål. $\AA$ analysere geografisk samsvar mellom sykdomsforekomst og tilbudsnivå er metodisk krevende selv for sykdommer med relativt entydige kriterier for alvorlighetsgrad og behandlingsopplegg slik som akutt hjerteinfarkt og lårhalsbrudd. Hvor store og stabile geografiske forskjeller i infarktrater må foreligge for å forsvare forskjeller i befolkningskorrigert sengekapasitet og annen ressurstilgang? Etter hvert som flere datagrunnlag blir enklere å samordne vil det øke muligheten for å besvare slike viktige spørsmål.

\section{HELSEATLASENES UTFORMING OG LAYOUT}

Begge atlasene har en god formgivning. Nasjonalatlaset har et meget forseggjort design med utsøkte fotografier som passer inn i tekst og tema. Ved å benytte uthevete faktaruter, ordforklaringer og stikkordsliste oppnås et fortrinn i leserveiledning. Kildeangivelser er oversiktlige og det foreligger en omfattende litteraturliste. Atlaset fungerer meget godt som oppslagsbok. Alt i alt preges Nasjonalatlaset av en lengere tid for ferdigstilling og en mer påkostet formgivning.

Hordalandsatlaset er til sammenligning noe enklere. Separat liste for ordforklaringer og indeks inngår ikke. Noen figurer er ufullstendige når de mangler angivelse av verdier på aksene. Men dette reduserer ikke et solid helhetsinntrykk også av dette bokverket. Atlasene har god trykk på kart og grafiske framstillinger samt høy papirkvalitet.

I kartverkene har en valgt å gå langt i å redegjøre for faguttrykk og begreper. Bare unntaksvis forekommer feil og ufullstendigheter i definisjoner og ordforklaringer, som når begge atlasene definerer en rate uten at tidsenhet er angitt. I Nasjonalatlaset sine ordforklaringer forekommer av og til en sviktende presisjon. En anvender f.eks. betegnelsen "ventelistegarantien" som egentlig er en ventetidsgaranti: Denne ordningen omfatter ikke alle pasientkategorier - bare de som har såkalt annenprioritet.

Atlasene har dekkende fortegnelser over presenterte figurer og kart. For begge atlasene savnes imidlertid en mer samlet oversikt over kart med geografiske områder og navn som en innledende del. Det ville også vært nyttig med et appendiks som viste nøkkeltall om befolkningen og dens utvikling fordelt etter aktuelle geografiske inndelinger. Et omfattende engelsk sammendrag i Nasjonalatlaset bidrar til å øke tilgjengeligheten for utenlandske lesere. Hordalandsatlaset nøyer seg her med en engelsk oversettelse av hovedtekst til kartene.

\section{AVSLUTNING}

Ut fra det som er nevnt foran er det betryggende å kunne konkludere med at atlasene svært langt på vei makter å utfylle hverandre. Dette til tross for fellestrekk i tematisk oppbygning og valg av sykdommer og tjenester som presenteres. Oppsiktsvekkende er det når nærmere 120 kartbilder i Hordalandsatlaset og rundt 150 i Nasjonalatlaset resulterer i kun fire kart som dekker samme variabel for samme geografisk enhet og tidsperiode! (Forventet levealder; andel røykere i ungdomsskolen, fylkeskommunale driftsutgifter til somatiske sykehus og totalt antall utskrivninger fra somatiske sykehus - alle på fylkesnivå.) Dette demonstrerer et tankevekkende poeng, nemlig det presentasjonsmangfold som foreligger for datagrunnlagene. Utvelgelse av materialet er basert på forskjellig ståsted med hensyn til regionalisering og tid. I en del tilfeller kan en diskutere hvilke enheter og beregningsmåter som er mest formålstjenlige. Uansett kan ulike valg gi rom for nyanser $\mathrm{i}$ en mangefasettert norsk helsevirkelighet.

Vinklingene i atlasene er forskjellige. Nasjonalatlaset gir en grundigere gjennomgang av grunnleggende forhold omkring metode og epidemiologi og likeledes hovedtrekk i helsetjenesten. Hordalandsatlaset er dristigere i presentasjon av samvariasjonsmønstre, erkjenner mulige metodesvakheter, og gjør sine valg eksplisitt etterprøvbare. Enkelte kapitler i atlaset synes ikke å være fullt ut gjennomarbeidet, noe forfatterne understreker tydelig $\mathrm{i}$ det atlaset lanseres som en pilotutgave. En kort tid for ferdigstilling skal berømmes. Dette må også sees i lys av at atlaset er et bemerkelsesverdig løft for en fylkeskommune, riktignok godt støttet av NSD. Atlaset gir dessuten et egnet oppslag for planlegging med et fylke som utgangspunkt. Andre fylkeskommuner vil måtte vurdere atlaset som en mulig mal for hva de kan utrette.

Likevel er det ikke å komme forbi at de to atlasene vil kunne konkurrere om de samme leserne. Uten å være panegyrisk må en si at begge bokverkene har en imponerende høy leservennlighet. De framstår som produkter av stor verdi. Atlasene er således viktige tilskudd til litteratur og oversikter over folkehelse og helsetjenester. Det er ikke lett å anbefale det ene framfor det andre. Ved parallelt å gå igjennom temakartene i de to bøkene gir de en synergieffekt som bør kunne utnyttes videre. 


\section{REFERANSER}

Cliff AD, Haggett P. Atlas of Disease Distributions. Oxford: Basil Blackwell, 1988.

Glattre E, Finne TE, Olesen O, Langmark F. Atlas over Kreftinsidens i Norge, 1970-79. Oslo: Kreftregisteret, 1985.

Jensen OM, Carstensen B, Glattre E, Malker B, Pukkula E, Tulinius H. Atlas of Cancer Incidence in the Nordic Countries. Helsinki: Nordic Cancer Union, 1988.

Mayer J. Relations between two traditions of medical geography: health systems planning and geographical epidemiology. Progress in Human Geography 1982; 6: 216-230.

McGlashan N. Some developments in disease atlas mapping in the 1970s and 1980s. Norsk Geografisk Tidsskrift 1990; 44: 211-219.

Sosial- og helsedepartementet. Folkehelserapporten. Oslo, 1996. 